\title{
Teaching NeuroImages: A disintegrating rock
}

Maximiliano A. Hawkes, MD, and Alejandro A. Rabinstein, MD

Neurology ${ }^{\circledR}$ 2019;92:e1937-e1938. doi:10.1212/WNL.0000000000007299
Correspondence

Dr. Hawkes

mhawkes@fleni.org.ar

Figure Brain and vascular imaging

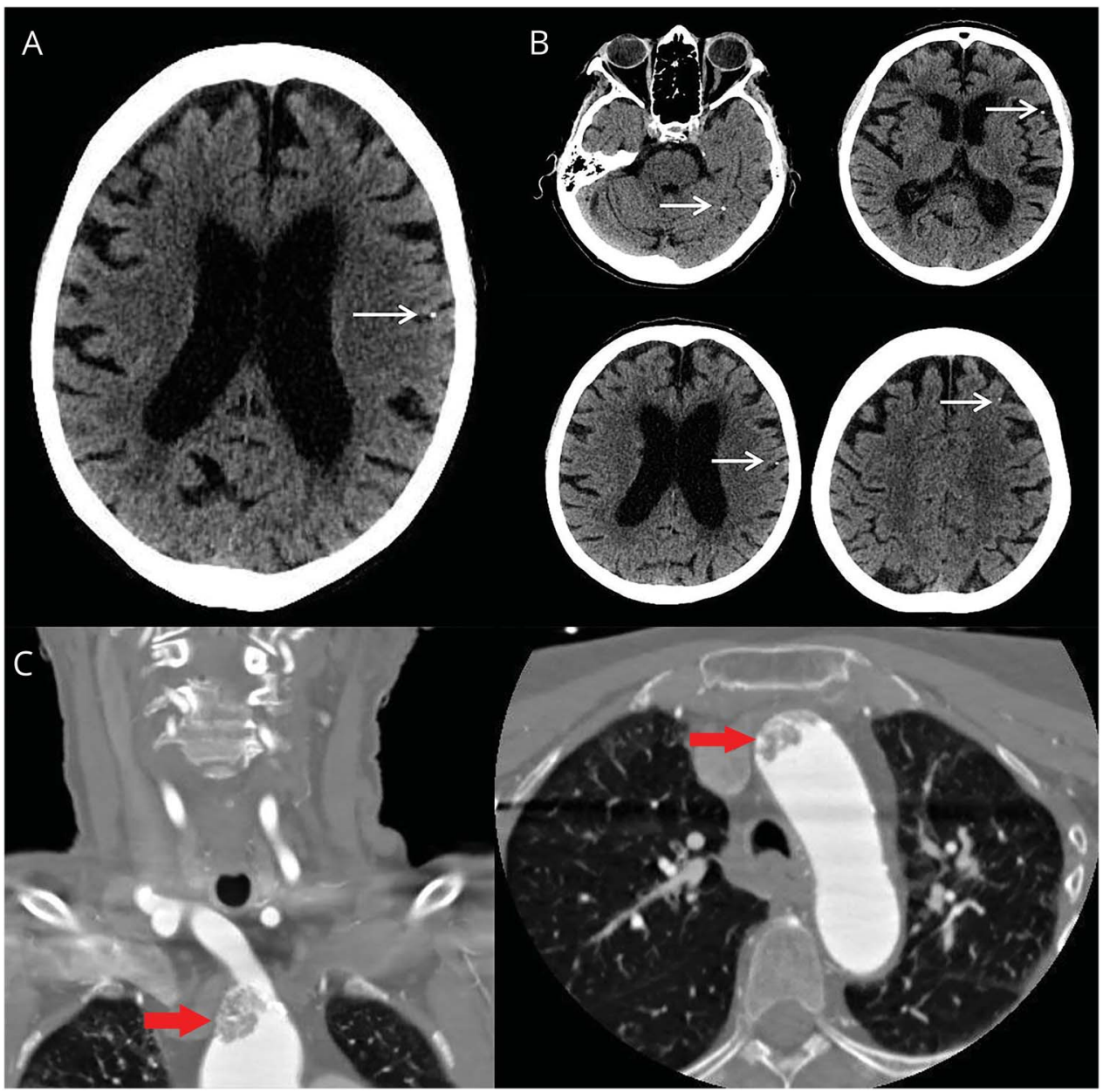

(A) Initial CT scan. Arrow points to a calcific embolus. (B) A repeat CT scan shows multiple calcific emboli (arrows). (C) CT angiogram of the neck. Arrows point to a large atheromatous plaque within the aortic arch extending into the origin of the brachiocephalic artery causing a $40 \%$ stenosis.
A 75-year-old woman with a history of hypertension, dyslipidemia, and atrial fibrillation on warfarin presented with sudden-onset confusion. A brain CT was read as normal. The international normalized ratio (INR) was 3.4. She was discharged home after resolution of her symptoms. Two weeks later, she presented with sudden-onset anomia and a right facial droop. The INR was 3.2. A new brain CT revealed multiple calcific emboli (figure, B). A CT angiogram showed a large atheromatous plaque within the aortic arch extending into the origin of the brachiocephalic artery (figure, C). Retrospectively, the initial CT already showed a calcified embolus (figure, A). Calcified cerebral emboli are frequently overlooked. ${ }^{1}$ Underlying sources may carry a high risk of recurrent embolism. Their early identification allows appropriate workup and treatment.

\section{MORE ONLINE}

$\rightarrow$ Teaching slides

links.lww.com/WNL/ A859 


\section{Study funding}

No targeted funding reported.

\section{Disclosure}

M. Hawkes reports no disclosures relevant to the manuscript. A. Rabinstein serves on the external committee for adverse event adjudication for PREVAIL Trial/CAP2 registry; serves as an associate editor of Neurocritical Care and on the editorial boards of Neurology ${ }^{\circledR}$, Stroke, and CONTINUUM; receives publishing royalties for Practical Neuroimaging in Stroke (Elsevier, 2009) and What To Do? Neurocritical Care (Oxford, 2016); and receives an unrestricted research grant from DJO Global for an investigator-initiated project. Go to Neurology. org/ $\mathrm{N}$ for full disclosures.
Appendix Authors

\begin{tabular}{|c|c|c|c|}
\hline Name & Location & Role & Contribution \\
\hline $\begin{array}{l}\text { Maximiliano } \\
\text { A Hawkes, } \\
\text { MD }\end{array}$ & FLENI & Author & $\begin{array}{l}\text { Design and drafting of the article, } \\
\text { acquisition and interpretation of } \\
\text { data. }\end{array}$ \\
\hline $\begin{array}{l}\text { Alejandro A } \\
\text { Rabinstein, } \\
\text { MD }\end{array}$ & $\begin{array}{l}\text { Mayo } \\
\text { Clinic }\end{array}$ & Author & $\begin{array}{l}\text { Design of the article, acquisition } \\
\text { and interpretation of data, } \\
\text { revision the article for intellectual } \\
\text { content }\end{array}$ \\
\hline
\end{tabular}

\section{Reference}

1. Walker BS, Shah LM, Osborn AG. Calcified cerebral emboli, a "do not miss" imaging diagnosis: 22 new cases and review of the literature. AJNR Am J Neuroradiol 2014;35: 1515-1519. 


\title{
Neurology
}

\author{
Teaching NeuroImages: A disintegrating rock \\ Maximiliano A. Hawkes and Alejandro A. Rabinstein \\ Neurology 2019;92;e1937-e1938 \\ DOI 10.1212/WNL.0000000000007299
}

This information is current as of April 15, 2019

\section{Updated Information \& Services}

\section{References}

Subspecialty Collections

Permissions \& Licensing

Reprints including high resolution figures, can be found at: http://n.neurology.org/content/92/16/e1937.full

This article cites 1 articles, 1 of which you can access for free at: http://n.neurology.org/content/92/16/e1937.full\#ref-list-1

This article, along with others on similar topics, appears in the following collection(s):

All Cerebrovascular disease/Stroke

http://n.neurology.org/cgi/collection/all_cerebrovascular_disease_strok $\mathrm{e}$

CT

http://n.neurology.org/cgi/collection/ct

Embolism

http://n.neurology.org/cgi/collection/embolism

Information about reproducing this article in parts (figures,tables) or in its entirety can be found online at:

http://www.neurology.org/about/about_the_journal\#permissions

Information about ordering reprints can be found online:

http://n.neurology.org/subscribers/advertise

Neurology ${ }^{\circledR}$ is the official journal of the American Academy of Neurology. Published continuously since 1951, it is now a weekly with 48 issues per year. Copyright @ 2019 American Academy of Neurology. All rights reserved. Print ISSN: 0028-3878. Online ISSN: 1526-632X.

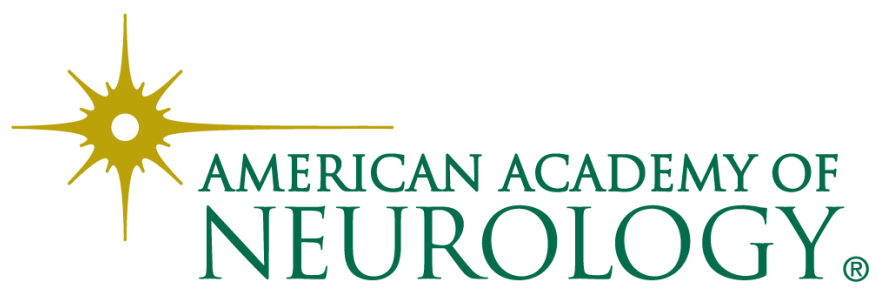

